\title{
Tritium and Argon-39 in Stone and Iron Meteorites
}

\author{
St. Charalambus, K. Goebel, and W. Stötzel-Riezler \\ European Organization for Nuclear Research, CERN, Genf, Schweiz \\ (Z. Naturforsch. 24 a, 234-244 [1969]; received 5 April 1968)
}

\begin{abstract}
Tritium and argon-39 measurements of stone and iron meteorites are reported and discussed. The tritium values of stone meteorites are in general higher than those found in other laboratories. The tritium decay rates in irons were low but a relatively high tritium value was measured in the rim of the meteorites. Factors which may influence the production rates are discussed and it is concluded that the average cosmic-ray flux which irradiated the meteorites must be at least a factor of two higher than the values reported by MacDonald for the cosmic-ray intensity at the top of the earth atmosphere.
\end{abstract}

During the last two years a number of publications have stimulated the discussion on cosmic-rayproduced tritium in meteorites. Encouraged by this we have re-examined our measurements which were completed a couple of years ago. A part of our earlier results has already been published ${ }^{1-6}$. However, we have to revise some of the data due to a re-determination of the counting efficiency, and because a large number of samples were re-measured in a proportional low-level tritium counter afterwards ${ }^{7}$. Studies of tritium diffusion through palladium ${ }^{8}$ have since been made, and we felt that the sampling method and the experimental procedure should be described in more detail, as this had not yet been done in earlier publications. New results, for instance the tritium concentration in the rim of iron meteorites, are also included in the present report.

Before we started our measurements, a number of tritium determinations were published, and since we completed this experiment some more measurements have been added. However, about one-third of all known tritium determinations in meteorites were made in our laboratory (measurements under the same experimental conditions).

Since, for the diffusion problems, the concentration of other rare gases in the meteoritic samples is of great importance, parallel measurements of

1 K. Goebel, P. Schmidlin, and J. Zähringer, Z. Naturforsch. 14 a, 996 [1959].

2 K. Goebel and P. Schmidlin, Geochim. Cosmochim. Acta 17, 342 [1959].

3 K. Goebel and P. Schmidlin, Z. Naturforsch. 15a, 79 [1960].

4 St. Charalambus and K. Goebel, Conference on Fission and Spallation Phenomena and their Application to Cosmic-rays, CERN, Sept. 1961.

5 St. Charalambus and K. Goebel, Geochim. Cosmochim. Acta 26, 659 [1962]. stable rare gases in the same sample were made by mass spectrometer analysis. For this purpose we collaborated with the group of Prof. GENTNER and Dr. J. ZäHRINGER at the Max-Planck-Institut für Kernphysik in Heidelberg.

\section{The Meteoritic Samples}

For all the meteorites for which tritium and argon-39 measurements are described below, the circumstances of the fall are known. Only such meteorites which fell within the last 50 years were chosen ( $\sim 4$ tritium half-lives). In the selection of the material, special preference was given to small meteorites.

Spectrographical analyses of the meteoritic samples were made by the Central Institute for Industrial Research, Oslo, Norway (Table 1). For this purpose, aliquots from each sample were prepared. Such aliquots were also sent for mass-spectrometrical analysis of rare gases to the Max-Planck-Institut für Kernphysik.

The chemical composition for Bruderheim was taken from Ref. ${ }^{8 a}$ and for Norton County from Ref. ${ }^{8 b}$. We used, instead of the spectrographical data for potassium (values in brackets), the mass spectrometrical data of KIRSTEN et al. ${ }^{50}$ and for the li-

${ }^{6}$ K. Goebel and P. Schmidlin, Radioisotopes in the Physical Science and Industry, IAEA, Vienna 1962.

$7 \mathrm{St}$. Charalambus and K. Goebel, Nucl. Instrum. Meth. 25, 109 [1963].

8 St. Charalambus and K. Goebel, Z. Naturforsch. 20 a, 1085 [1965].

8a H. Baadsgaard, F. A. Champbell, R. E. Folinsbee, and G. L. Cumming, J. Geophys. Res. 66, 3574 [1961].

8 b. W. BECK and L. LAPAZ, Am. Mineralog. 36, 45 [1951].
Dieses Werk wurde im Jahr 2013 vom Verlag Zeitschrift für Naturforschung in Zusammenarbeit mit der Max-Planck-Gesellschaft zur Förderung der Wissenschaften e.V. digitalisiert und unter folgender Lizenz veröffentlicht: Lizenz.

Zum 01.01.2015 ist eine Anpassung der Lizenzbedingungen (Entfall der Creative Commons Lizenzbedingung „Keine Bearbeitung“) beabsichtigt, um eine Nachnutzung auch im Rahmen zukünftiger wissenschaftlicher Nutzungsformen zu ermöglichen.
This work has been digitalized and published in 2013 by Verlag Zeitschrift für Naturforschung in cooperation with the Max Planck Society for the Advancement of Science under a Creative Commons Attribution-NoDerivs 3.0 Germany License. 


\begin{tabular}{|c|c|c|c|c|c|c|c|c|c|c|c|c|}
\hline Name & Class & $\begin{array}{c}\mathrm{O} \\
\times 10^{22}\end{array}$ & $\begin{array}{c}\mathrm{Fe} \\
\times 10^{21}\end{array}$ & $\begin{array}{l}\mathrm{Si} \\
\times 10^{21}\end{array}$ & $\begin{array}{c}\mathrm{Mg} \\
\times 10^{21}\end{array}$ & $\begin{array}{c}\mathrm{Ni} \\
\times 10^{20}\end{array}$ & $\begin{array}{c}\mathrm{Ca} \\
\times 10^{20}\end{array}$ & $\begin{array}{c}\mathrm{Al} \\
\times 10^{20}\end{array}$ & $\begin{array}{c}\mathrm{Na} \\
\times 10^{20}\end{array}$ & $\begin{array}{r}\mathrm{K} \\
\times 10\end{array}$ & $0^{19}$ & $\begin{array}{l}\mathrm{Li} \\
\times 10^{17}\end{array}$ \\
\hline Abee & $\mathrm{CeK}$ & 1.47 & 3.45 & 3.1 & 2.2 & 2.2 & 1.60 & 3.1 & 1.26 & $(1.2)$ & 1.3 & 1.1 \\
\hline \multicolumn{2}{|l|}{ Ordinary chondrites } & 1.37 & 3.0 & 3.9 & 3.1 & 1.7 & 1.05 & 2.2 & 1.9 & & 1.3 & - \\
\hline Nadiabondi & $\mathrm{C}$ & 1.51 & 3.13 & 3.5 & 2.4 & 2.10 & 1.40 & 2.0 & 1.07 & & 1.3 & - \\
\hline Forest Vale & $\mathrm{C}$ & 1.43 & 3.13 & 3.5 & 3.0 & 1.38 & 1.84 & 3.6 & 1.4 & & 1.3 & $\overline{08}$ \\
\hline $\begin{array}{l}\text { Ramsdorf II } \\
\text { Bruderheim }\end{array}$ & $\begin{array}{l}\mathrm{Cb} \\
\mathrm{C}\end{array}$ & 1.58 & 2.59 & 3.5 & $\begin{array}{l}3.2 \\
3.7\end{array}$ & 1.44 & 2.04 & 2.6 & $\begin{array}{l}0.97 \\
1.95\end{array}$ & $\begin{array}{l}(1.2) \\
(1.2)\end{array}$ & $\begin{array}{l}1.3 \\
1.4\end{array}$ & $\begin{array}{l}0.8 \\
0.9\end{array}$ \\
\hline Ramsdorf I & $\mathrm{Cb}$ & 1.55 & 1.94 & 4.5 & $\begin{array}{l}5.6 \\
3.5\end{array}$ & 1.30 & $\begin{array}{l}1.2 \\
2.7\end{array}$ & 3.9 & 3.1 & $(1.2)$ & $\begin{array}{l}1 . \pm \\
1.3\end{array}$ & - \\
\hline Meru & $\mathrm{Cib}$ & 1.85 & 1.94 & 4.1 & 3.6 & 2.83 & 2.4 & 4.2 & 1.26 & & 1.3 & - \\
\hline Elenovka & $\mathrm{Ck}$ & 1.55 & 1.83 & 4.5 & 3.1 & 3.25 & 2.3 & 4.5 & 3.1 & & 1.55 & - \\
\hline Kapoeta & & 1.73 & 1.51 & 4.5 & 2.2 & 0.12 & 5.6 & 13.0 & 1.0 & & 0.25 & - \\
\hline Macibini & $\mathrm{Eu}$ & 1.66 & 1.24 & 4.5 & 1.04 & $<0.01$ & 10.8 & 21 & 1.26 & & 0.60 & - \\
\hline Eucrites & & 1.59 & 1.5 & 4.8 & 1.27 & - & 10.9 & 15.2 & 0.84 & & 0.77 & - \\
\hline Tataouine & Di & 1.58 & 0.93 & 6.0 & 3.2 & $<0.01$ & 1.08 & 1.17 & 0.1 & & 0.03 & 0.8 \\
\hline Penablanca Spring & $\mathrm{Au}$ & 1.70 & 0.054 & 5.2 & 6.7 & $<0.01$ & 1.7 & 4.3 & 1.26 & $(<1.2)$ & 0.45 & - \\
\hline Norton County & $\mathrm{Au}$ & 1.80 & 0.049 & 5.7 & 5.9 & 0.035 & 1.78 & 0.83 & 0.20 & $(0.34)$ & 0.11 & - \\
\hline Aubrites & & 1.80 & - & 5.5 & 5.4 & - & 0.98 & 0.77 & 2.6 & & 1.2 & - \\
\hline
\end{tabular}

Table 1. Chemical composition - Atoms per gramme of meteorite. Errors are $10-20 \%$ for $\mathrm{Li}, \mathrm{Na}$ and $\mathrm{K}$ and $5-10 \%$ for all other elements.

thium content the activation analysis of KRANKOwSKY and MÜLLER ${ }^{8 c}$. The results of Table 1 were used for an estimation of the tritium and argon-39 production in meteorites. For tritium the main constituent of the meteorites, and for argon-39 iron, nickel and potassium ${ }^{8 \mathrm{~d}}$ are of importance. The lithium content is of interest for an estimation of the tritium production by neutron capture. The individual measurements can be compared with average values given for ordinary chondrites, eucrites and aubrites ${ }^{8 \mathrm{e}}$.

The meteoritic samples were stored in glass containers. The storage room was kept free from any radioactivity. The storage temperature was between $20{ }^{\circ} \mathrm{C}$ and $26^{\circ} \mathrm{C}$, the average humidity lower than $60 \%$ in winter and $70 \%$ in summer. The stone samples were cut on a clean working table with hammer and chisel. Then they were ground to grain sizes ranging from some tenthts of a $\mathrm{mm}$ to a few $\mathrm{mm}$. Using a hand saw, the iron samples were cut slowly enough to avoid undue heating. Individual pieces of the samples were on the average much bigger than in the case of stones. All tools used were carefully checked for contamination by means of dummy experiments. The samples were carefully mixed and different aliquots prepared. For tritium and argon-39 measurements, samples weighing between 10 and $20 \mathrm{~g}$ were introduced into the sample tube of the degassing line and pumped for some hours, before the gas extraction started.

8c D. Krankowsky and O. Müller, Geochim. Cosmochim. Acta 28, 1625 [1964].

$8 d$ F. Begemann, E. Vilcsek, and E. Wänke, Earth and Planetary Sc. Lett. 3, 207 [1967].

\section{Experimental Procedure}

Figure 1 presents the degassing apparatus for the extraction of tritium and argon-39 from the samples. The samples were heated by induction heating to about $1700{ }^{\circ} \mathrm{C}$ under vacuum. Hydrogen was separated from the bulk of the gases by diffusion through hot palladium. The hydrogen was pumped into a tritium counter (either GM or proportional counter) and the rare gases after purification into a small GM counter. The most important details are described below.

\subsection{Extraction of tritium and argon-39}

For coupling with the high-frequency field, we used an outer crucible of molybdenum, a material which, from our experience, gives good results with respect to complete extraction of hydrogen and which does not evaporate extensively. After many trials we selected alumina as being the most suitable material for lining the Mo crucible in order to protect it against the reaction with the stone and iron melt. In some cases, however, we had chemical reactions between the alumina and the meteorites at very high temperature. In order to avoid a violent evaporation of the sample, we placed an alumina lid on top of the crucible.

Table 2 presents the degassing procedure and the different operational conditions. The gases freed from the sample, operation 5 , were continuously pumped into

$8_{e}$ D. Wood, Physics and Chemistry of Meteorites, in the Moon, Meteorites and Comets IV, edited by B. H. MiddleHURst and G. P. Kuiper, Univers. of Chicago Press 1963. 


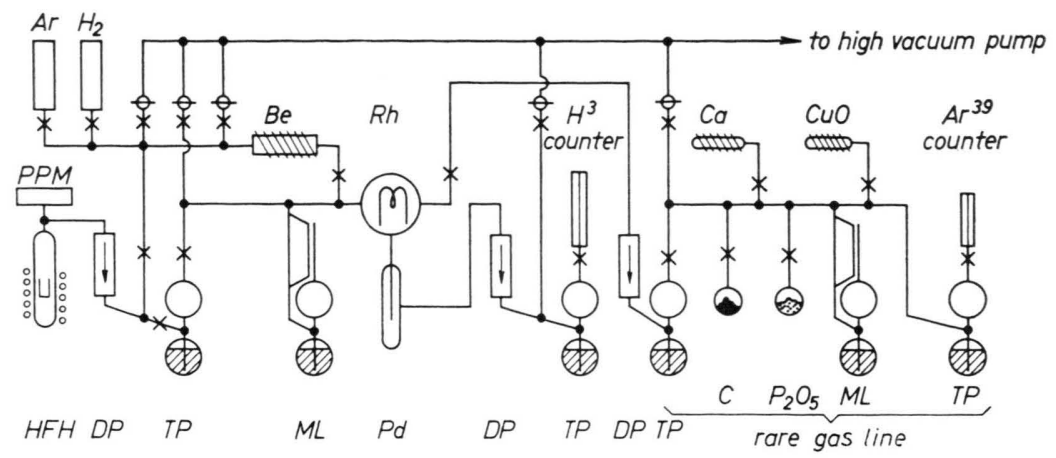

Fig. 1. Gas extraction apparatus. HFH: high frequency heater. PPM: preheating place of meteorite. Ar, $\mathrm{H}_{2}$ : Argon and hydrogen carrier reservoir. DP: Hgdiffusion pump for gas transfer. TP: Automatic Toepler pump for gas transfer. Be: Be-filled furnace for water decomposition. ML: MacLeod manometer $\left(10^{-6}\right.$ Torr $) . \mathrm{Pd}$ : Palladium thimble for T-diffusion. Rh: Rhodium unit for hydrocarbon cracking. C: Charcoal for gas absorption. $\mathrm{P}_{2} \mathrm{O}_{5}$ : Water absorber. Ca: $\mathrm{Ca}$-filled furnace. $\mathrm{CuO}$ : CuO-filled furnace. X: Mercury stopcock.

\begin{tabular}{|c|c|c|c|c|c|}
\hline & Operation & $\begin{array}{l}\text { Time } \\
\text { schedule; } \\
\text { hours }\end{array}$ & Place of sample & Temperature & Conditions \\
\hline 1) & $\begin{array}{l}\text { Degassing of } \\
\text { apparatus }\end{array}$ & $0-4$ & $\begin{array}{l}\text { Inside vacuum line } \\
\text { but not yet in } \\
\text { crucible }\end{array}$ & Room temperature & Gas pumped off \\
\hline & $\begin{array}{l}\text { Degassing of } \\
\text { crucible }\end{array}$ & $4-6$ & As in 1 & $\begin{array}{l}\text { Crucible } 1700^{\circ} \mathrm{C} \\
\text { sample: room temperat. }\end{array}$ & $\begin{array}{l}\text { Liberated gas pumped } \\
\text { off }\end{array}$ \\
\hline 3) & $\begin{array}{l}\text { Cooling down and } \\
\text { "saturation" with } \\
\mathrm{H}_{2}\end{array}$ & $6-7$ & As in 1 & $\begin{array}{l}\text { Cooling down from } \\
1700^{\circ} \mathrm{C} \text { to room } \\
\text { temperature under } \\
\text { hydrogen atmosphere }\end{array}$ & $3-4$ Torr $\mathrm{H}_{2}$ \\
\hline 4) & $\begin{array}{l}\text { Sample introduced } \\
\text { in crucible }\end{array}$ & & In crucible & Room temperature & Free gas pumped off \\
\hline 5) & $\begin{array}{l}\text { Extraction of gases } \\
\text { from meteorites }\end{array}$ & $7 \sim 10$ & In crucible & $1650^{\circ} \mathrm{C}$ & \multirow{2}{*}{$\begin{array}{c}\text { Extracted gases tre } \\
\text { ferred to separatior } \\
3-4 \text { Torr } \mathrm{H}_{2} ; \\
\sim 5-7 \text { torr } \cdot \text { litre } \\
0.2 \text { Torr Ar; } \\
\sim 0.35 \text { torr } \cdot \text { litre }\end{array}$} \\
\hline 6) & $\begin{array}{l}\mathrm{H}_{2} \text { carrier } \\
\text { Ar carrier }\end{array}$ & $10 \sim 11$ & In crucible & $1650^{\circ} \mathrm{C}$ & \\
\hline
\end{tabular}

Table 2. Degassing procedure.

the middle part of the vacuum line by means of a mercury diffusion pump and an automatic Toepler pump. After a heating period of about 2 to 3 hours, carrier hydrogen and argon were added and the sample reheated for about half an hour in a hydrogen and argon atmosphere. This hydrogen was in turn transferred to the separation line. As considerable quantities of water can be extracted from some meteorites, we had to transform the water into hydrogen. This was done by hot beryllium $\left(1000{ }^{\circ} \mathrm{C}\right)$. The decomposition of water was accelerated considerably by using a circulating gas flow through the hot beryllium oven. A hot rhodium filament was used to crack hydrocarbons. The residual gas which did not diffuse through hot $\mathrm{Pd}$ (mainly a mixture of $\mathrm{O}, \mathrm{N}$ and noble gases) was purified using $\mathrm{Ca}$ and $\mathrm{CuO}$ furnaces. For each extraction the procedure was re-cycled (operations 5 and 6) and the gases from the second run put in another GM counter. From these runs we found that after the first heating cycle, the remaining gases were less than $10 \%$ of the previous quantity. Before starting, a blank was done to check the procedure and the background of the whole gas-handling equipment.
An experiment was performed for determining the diffusion conditions of hydrogen isotopes through palladium. It was shown ${ }^{8}$ that at a palladium temperature of $450{ }^{\circ} \mathrm{C}$ (our particular working conditions), practically all tritium diffused through palladium.

\subsection{The counters and counting procedure}

The GM counters for tritium are Kovar-metal cylinders of $40 \mathrm{~mm}$ diameter and $210 \mathrm{~mm}$ length (volume: about $150 \mathrm{~cm}^{3}$ ), with a $0.09 \mathrm{~mm}$ stainless-steel centre wire. About 100 Torr self-quenching gas (55\% argon and $45 \%$ ethylene) was used. A good plateau of $300 \mathrm{~V}$ length with less than $3 \%$ per $100 \mathrm{~V}$ slope was obtained. The counter characteristics were essentially the same when up to 200 Torr hydrogen was added.

The GM counter for argon-39 had a volume of about $10 \mathrm{~cm}^{3}$, a diameter of $10 \mathrm{~mm}$ and was $80 \mathrm{~mm}$ long, with a plateau of $100 \mathrm{~V}$ length.

Three tritium-GM counters were placed simultaneously in an anticoincidence ring of 36 GM counters which vetoed the events from charged environmental particles. The whole anti-coincidence apparatus was placed in a shield of $20 \mathrm{~cm}$ iron with an additional 


\begin{tabular}{|c|c|c|c|c|c|c|c|}
\hline \multirow{2}{*}{$\begin{array}{c}\text { Meteorite, } \\
\text { recovered mass, } \\
\text { fall date, supplier }\end{array}$} & \multirow[b]{2}{*}{$\begin{array}{c}\text { Run } \\
\text { counter }\end{array}$} & \multirow[b]{2}{*}{$\begin{array}{c}\text { G-M } \\
\text { counter }\end{array}$} & \multicolumn{2}{|c|}{${ }^{3} \mathrm{H}$ content $(\mathrm{dpm} / \mathrm{g})$} & \multirow[b]{2}{*}{$\begin{array}{l}\text { From other } \\
\text { laborator. }\end{array}$} & \multicolumn{2}{|c|}{${ }^{39} \mathrm{~A}(\mathrm{dpm} / \mathrm{kg})$} \\
\hline & & & Prop. & $\begin{array}{c}\text { Aver- } \\
\text { age } * * *\end{array}$ & & $\begin{array}{l}\text { Present } \\
\text { work }\end{array}$ & $\begin{array}{l}\text { Other } \\
\text { laborator. }\end{array}$ \\
\hline $\begin{array}{l}\text { Abee } 100 \mathrm{~kg} \\
(10.6 .1952) \\
\text { K. Dawson }\end{array}$ & $\begin{array}{l}\text { M1 } \\
\text { M2 } \\
\text { M3 } \\
\text { M20 }\end{array}$ & $\begin{array}{l}0.75 \\
1.48 \\
0.67 \\
1.56\end{array}$ & 1.48 & $\begin{array}{l}1.1 \\
(0.76)\end{array}$ & $0.26^{9}$ & & \\
\hline $\begin{array}{l}\text { Bruderheim } 180 \mathrm{~kg} \\
(4.3 .1960) \\
\text { R.E. Folinsbee }\end{array}$ & $\begin{array}{l}\text { M37 } \\
\text { M42 } \\
\text { M43 }\end{array}$ & $\begin{array}{l}0.59 \\
0.49 \\
0.41\end{array}$ & $\begin{array}{l}0.40 \\
0.49 \\
0.40\end{array}$ & $\begin{array}{c}0.46 \\
(0.58)\end{array}$ & $\begin{array}{l}0.495^{10} \\
0.494^{10} \\
0.26^{11}\end{array}$ & 14.5 & $\begin{array}{l}10^{15} \\
10.5^{11} \\
11.5^{16} \\
23.0^{17 *}\end{array}$ \\
\hline $\begin{array}{l}\text { Elenovka } 54.4 \mathrm{~kg} \\
(17.10 .1951) \\
\text { E. Krinov }\end{array}$ & M44 & 0.64 & 0.58 & $\begin{array}{c}0.60 \\
(0.90)\end{array}$ & $0.40^{12}$ & & \\
\hline $\begin{array}{l}\text { Forest Vale } 30 \mathrm{~kg} \\
(7.8 .1942) \\
\text { R. O. Chalmers }\end{array}$ & $\begin{array}{l}\text { M41 } \\
\text { M45 }\end{array}$ & $\begin{array}{l}2.35 \\
0.97\end{array}$ & $\begin{array}{l}1.73 \\
0.85\end{array}$ & $\begin{array}{l}1.5 \\
(1.1)\end{array}$ & & 13.1 & \\
\hline $\begin{array}{l}\text { Kapoeta } 11.3 \mathrm{~kg} \\
(22.4 .1942) \\
\text { M. A. Abdulla }\end{array}$ & $\begin{array}{l}\text { M36 } \\
\text { M40 }\end{array}$ & $\begin{array}{l}1.57 \\
1.87\end{array}$ & 1.47 & $\begin{array}{l}1.64 \\
(1.2)\end{array}$ & & 18.8 & \\
\hline $\begin{array}{l}\text { Kunashak } 200 \mathrm{~kg} \\
\text { (11. } 6.1949) \\
\text { E. Krinov }\end{array}$ & M32 & 0.60 & 0.49 & $\begin{array}{c}0.55 \\
(0.64)\end{array}$ & $0.46^{12}$ & 20.3 & \\
\hline $\begin{array}{l}\text { Macibini } 2 \mathrm{~kg} \\
(23.9 .1936) \\
\text { L. O. Nicolaysen }\end{array}$ & $\begin{array}{l}\text { M8 } \\
\text { M13 }\end{array}$ & $\begin{array}{l}1.43 \\
0.73\end{array}$ & $\begin{array}{l}1.45 \\
0.37\end{array}$ & $\begin{array}{c}0.90 \\
(0.85)\end{array}$ & & & \\
\hline $\begin{array}{l}\text { Meru } 5.9 \mathrm{~kg} \\
(2.2 .1945) \\
\text { L. S. Leakey }\end{array}$ & M47 & 1.4 & 0.93 & $\begin{array}{c}1.17 \\
(1.15)\end{array}$ & & & \\
\hline $\begin{array}{l}\text { Nadiabondi } 3.6 \mathrm{~kg} \\
(27.7 .1956) \\
\text { J. Orcel }\end{array}$ & $\begin{array}{l}\text { M11 } \\
\text { M12 }\end{array}$ & $\begin{array}{l}0.98 \\
0.77\end{array}$ & & $\begin{array}{r}0.87 \\
(1.0)\end{array}$ & $0.14^{13}$ & 8.5 & $1.1^{13}$ \\
\hline $\begin{array}{l}\text { Norton County } \\
1 \text { ton }(18.2 .1948) \\
\text { L. LaPaz }\end{array}$ & $\begin{array}{l}\text { M35 } \\
\text { M38 } \\
\text { M39 }\end{array}$ & $\begin{array}{l}0.68 \\
0.44 \\
0.37\end{array}$ & $\begin{array}{l}0.46 \\
0.42 \\
0.36\end{array}$ & $\begin{array}{c}0.47 \\
(0.42)\end{array}$ & $\begin{array}{l}0.14^{13} \\
0.26^{14}\end{array}$ & 8.5 & $1.1^{13}$ \\
\hline $\begin{array}{l}\text { Penablanca Spring } \\
70 \mathrm{~kg}(2.8 .1946) \\
\text { H. H. Nininger }\end{array}$ & $\begin{array}{l}\text { M33 } \\
\text { M34 }\end{array}$ & $\begin{array}{l}0.70 \\
0.91\end{array}$ & & $\begin{array}{c}0.80 \\
(0.82)\end{array}$ & & $<2.0$ & \\
\hline $\begin{array}{l}\text { Ramsdorf } 9 \mathrm{~kg} \\
(26.7 .1958) \\
\text { K. Meisohle }\end{array}$ & $\begin{array}{l}\text { M4 } \\
\text { M6 } \\
\text { M9 } \\
\text { M 15 } \\
\text { M46** }\end{array}$ & $\begin{array}{l}0.47 \\
0.84 \\
1.09 \\
1.85 \\
0.83\end{array}$ & $\begin{array}{l}0.44 \\
1.00 \\
\\
0.72\end{array}$ & $\begin{array}{c}0.90 \\
(1.2)\end{array}$ & & & \\
\hline $\begin{array}{l}\text { Tataouine } 12 \mathrm{~kg} \\
(27.7 .1931) \\
\text { J. Orcel }\end{array}$ & $\begin{array}{l}\text { M7 } \\
\text { M10 }\end{array}$ & $\begin{array}{l}0.13 \\
0.14\end{array}$ & 0.375 & $\begin{array}{c}0.21 \\
(1.2)\end{array}$ & & & \\
\hline
\end{tabular}

* Metal phase of Bruderheim meteorite.

* Sample M 46 was found a few $\mathrm{km}$ distant from the first recovered stone ${ }^{18}$.

*** Average values in parentheses are deduced from curve in Fig. 2.

Table 3. Tritium and Argon-39 contents in stone meteorites.

9 F. Begemann, P. Eberhardt, and D. C. Hess, Z. Naturforsch. 14 a, 500 [1959].

10 A. E. Bainbridge, H. Suess, and H. Wänke, Geochim. Cosmochim. Acta 26, 471 [1962].

11 E. Fireman and J. DE Felice, J. Geophys. Res. 66, 3347 [1961].

12 J. Geiss, B. Hirt, and H. Oeschger, Helv. Phys. Acta 33, 590 [1960].

13 E. Fireman and J. De Felice, Geochim. Cosmochim. Acta 18, 183 [1960].
14 F. Begemann, J. Geiss, and D. Hess, Phys. Rev. 107, 540 [1957].

15 M. Honda, S. Umemoto, and J. R. Arnold, J. Geophys. Res. 66, 3541 [1961].

16 R. Davis, R. Stoenner, and O. Schaeffer, Radioactive Dating, IAEA, Vienna 1963, p. 355.

17 D. Tilles, J. De Felice, and E. Fireman, J. Geophys. Res. 67, 3604 [1962].

18 K. Meisohle, Ramsdorf, Kreis Borken. Personal communication. 
layer of $20 \mathrm{~cm}$ of lead on top. For the small argon counters, an anti-coincidence system was used consisting of a plastic scintillator, which had a slightly higher anti-coincidence efficiency than the GM counter ring. Under these conditions the background of the GM counters for tritium was $\leqq 2.5 \mathrm{cpm}$, and for the argon counters about $0.2 \mathrm{cpm}$.

The counting rates measured in the GM counters became stable about $1-2$ days after adding hydrogen. The counting of tritium and argon-39 was extended over more than a week, in many cases up to a month. Only after the stabilization period the counting rates (measured at intervals of 12 hours) were considered for the evaluation of the decay rates.

The special proportional counter used for precise tritium measurements was described elsewhere ${ }^{7}$. The background and stability of the counter were very satisfactory. For the $600 \mathrm{~cm}^{3}$ volume, a background of only 0.30 to $0.35 \mathrm{cpm}$ was obtained. (For more details, see Ref. ${ }^{7}$.)

The counters were calibrated using (i) a tritiated water standard supplied by the NBS; (ii) "reference" tritium and argon-39 gaseous sources; the absolute activity of these sources was determined by a special GM counter which had a $\beta$ window all along its cylindrical wall, allowing a precise determination of the sensitive volume with a collimated $\beta$ source.

\section{Results}

The tritium concentrations measured by the method described above are listed in Table 3. For most of the meteorites, more than one tritium measurements was made. For a single meteorite, tritium values scatter considerably, but we estimate that only a small part of these variations is due to experimental uncertainties. All parameters possibly influencing the result were studied extensively, for example, the degassing of the sample, the diffusion through palladium, the counter plateau, the stabilizing time for the counter and the background fluctuations. We estimate that all these influences contribute to a maximum error of $30 \%$ (see also next chapter).

The fact that tritium measurements on the same gas samples were done with a GM counter and with a proportional counter made it possible to reduce systematic errors of the activity determination.

In our laboratory, tritium production in targets was measured using a very similar apparatus. This allowed to study all the effects influencing the extraction procedure more easily because of the higher tritium activities involved.

\begin{tabular}{|c|c|c|c|c|c|c|c|c|}
\hline \multirow{2}{*}{$\begin{array}{l}\text { Meteorite, } \\
\text { recovered } \\
\text { mass, fall } \\
\text { date, supplier }\end{array}$} & \multirow[b]{2}{*}{ Run } & \multirow[b]{2}{*}{$\begin{array}{l}\text { Place of } \\
\text { sample }\end{array}$} & \multicolumn{2}{|c|}{${ }^{3} \mathrm{H}(\mathrm{dpm} / \mathrm{kg})$} & \multirow{2}{*}{$\begin{array}{c}{ }^{3} \mathrm{H}\left(\mathrm{dpm} / \mathrm{cm}^{2}\right) \\
\text { Surface } \\
\text { content }\end{array}$} & \multirow{2}{*}{$\begin{array}{l}{ }^{3} \mathrm{H}(\mathrm{dpm} / \mathrm{kg}) \\
\text { From other } \\
\text { laborator. }\end{array}$} & \multicolumn{2}{|c|}{${ }^{39} \mathrm{Ar}(\mathrm{dpm} / \mathrm{kg})$} \\
\hline & & & $\begin{array}{l}\text { G-M } \\
\text { counter }\end{array}$ & $\begin{array}{l}\text { Proportion. } \\
\text { counter }\end{array}$ & & & $\begin{array}{l}\text { Present } \\
\text { work }\end{array}$ & $\begin{array}{l}\text { Other } \\
\text { laborator. }\end{array}$ \\
\hline \multirow{5}{*}{$\begin{array}{l}\text { Aroos } 150 \mathrm{~kg} \\
(24.11 .1959) \\
\text { E. Krinov }\end{array}$} & M 25 & \multirow{5}{*}{$\begin{array}{l}\text { inner } \\
\text { surface } \\
1.5 \mathrm{~cm}^{2} \\
\text { inner }\end{array}$} & 9.0 & 16.0 & \multirow{5}{*}{2.80} & \multirow{5}{*}{$\begin{array}{l}50^{21} \\
10^{10}\end{array}$} & 20.7 & \multirow{5}{*}{$\begin{array}{l}17.2^{23,26} \\
23^{21} \\
16^{15} \\
16.3^{25} \\
16.8^{24}\end{array}$} \\
\hline & M 26 & & 270 & 250 & & & 16.1 & \\
\hline & & & & & & & & \\
\hline & M 27 & & 17 & & & & 17.1 & \\
\hline & & & & & & & & \\
\hline \multirow{5}{*}{$\begin{array}{l}\text { Sikhote Alin } \\
23 \text { tons } \\
(12.2 .1947) \\
\text { E. Krinov }\end{array}$} & M 28 & \multirow{5}{*}{$\begin{array}{l}\text { surface } \\
4.15 \mathrm{~cm}^{2} \\
\text { inner } \\
\text { inner } \\
\text { surface }\end{array}$} & 330 & & \multirow[t]{5}{*}{2.85} & \multirow{5}{*}{$1 \pm 4^{12}$} & & $4.8^{13}$ \\
\hline & & & & & & & & $4.25^{13}$ \\
\hline & M 29 & & 11 & 17 & & & & $5.5^{25}$ \\
\hline & M30 & & 60 & & & & 23.0 & 6.727 \\
\hline & M31 & & 610 & 510 & & & 18.9 & $6.3^{24}$ \\
\hline \multirow{4}{*}{$\begin{array}{l}\text { Treysa } 63 \mathrm{~kg} \\
(3.4 .1916) \\
\text { W. Gentner }\end{array}$} & $\mathrm{M} 48$ & \multirow[t]{4}{*}{ inner } & & & & & \multirow[t]{4}{*}{27.4} & $20.3^{26}$ \\
\hline & & & & & & & & $13.3^{13}$ \\
\hline & & & & & & & & $22.1^{25}$ \\
\hline & & & & & & & & $22.5^{24}$ \\
\hline
\end{tabular}

Table 4. Tritium and Argon contents in iron meteorites.

19 F. Begemann, Earth and Planetary Science Letters 1, 148 [1966].

20 J. Geiss and H. Oeschger, Space Research, Proc. of the First Int. Space Science Symposium, Nice 11-16 January, 1960 (Ed. by. H. K. KallmanN).

21 E. Fireman and J. De Felice, J. Geophys. Res. 65, 3032 [1960].

22 E. Fireman, SAO Preprints in Meteorites (Smithsonian Astrophysical Observatory), June 1967.

23 E. VILCSEK and H. WÄNKE, Max-Planck-Institut für Chemie, Mainz, Report No. 52 [1962].
24 O. Schaeffer and D. Heymann, J. Geophys. Res. 70, 215 [1965].

25 D. Heymann and O. Schaeffer, Physica 28, 1318 [1962].

${ }^{26}$ H. WÄnke, Max-Planck-Institut für Chemie, Mainz, Report No. 60 [1964].

27 E. Sprenkel, R. Davis, and E. Wigg, Bull. Am. Phys. Soc., April 1959, p. 223.

28 Because of the large amounts of hydrogen (carrier hydrogen and gas from the sample), two or three GM counters had to be used; the large error is due to small differences between sample counting rates and the background rates. 
Some samples from the surface of the iron meteorites Sikhote-Alin and Aroos have been examined for tritium. The results are presented in Table 4 . The high tritium concentration in the rim is surprising. We shall discuss this below.

The argon-39 results are given in Tables 3 and 4 . The values are essentially the same as in our previous publications. A re-calibration of the counters raised the activity level by about $20 \%$. The errors due to statistics and to background fluctuations are larger than for tritium, but the degassing, chemical and diffusion problems are simpler; therefore, the over-all error is estimated to be $30 \%$. In spite of the differing chemical composition of the samples, the total variations are smaller than for the tritium results.

\section{Discussion of the Results}

We would like to discuss the results of Table 3 from different aspects: (a) a comparison of the GM counter measurements and the proportional counter measurements; (b) sources for the scattering of the tritium content of different samples of the same meteorite, and (c) the discrepancies between the present values and results of other laboratories.

(a) For nearly all measurements the results for tritium concentration measured by the GM counter and by the proportional counter are within the limit of errors the same. Only for two measurements, Macibini (M 13) and Tataouine (M 10), the values obtained by the two counters show larger differences. For Tataouine the counting statistics are the lowest of all measurements (because of the early fall date and the small amount of material available), so that we had to allow for an exceptionally high error of $70 \%$ for the GM counter ${ }^{28}$ and about $40 \%$ for the proportional counter. In the case of Macibini the counting statistics are better. We attribute the discrepancy between the two measurements to accidental tritium losses during the transfer of the gas from one counter to the other. In principle, the confidence level is higher for the proportional counter measurements as only pulses are accepted which correspond to a $\beta$ energy between 1.5 and $20 \mathrm{keV}$, and as the background of the proportional counter is much lower than the one of the GM counter.

(b) For some meteorites the values measured in different samples show large differences. High fluctuations are found for Ramsdorf, Forest Vale, Abee and Macibini. The counting statistics in all cases are lower than $20 \%$ and because of the agreement between GM and proportional counter measurements we must assume that we have real differences in the tritium concentrations. We assume that in principle the higher tritium values for a meteorite have a higher confidence level as we cannot expect tritium gains but rather losses. It was checked by blanks that no tritium was left in the apparatus before starting each run. We also have to allow for the possibility that even neighbouring parts of the same meteorite have different tritium concentrations.

(c) For five of the stone meteorites on our list, tritium measurements have been published by other authors. For two of the five meteorites, i. e. Abee and Norton County, our values are up to a factor 4 or 3 higher than the tritium values found in other laboratories. However, for Norton County there exist also in the literature values a factor of two different from each other and the same is the case for Bruderheim. For these differences we can only use the general argument given above.

We found for the tritium content of Bruderheim, Kunashak and Elenovka good agreement with the published values, but our average values are, in general, a factor of 2 higher than the results of other laboratories for all meteorites. The only obvious explanation for this fact might be that extraction of tritium from the meteorite samples is in general more complete with our procedure ${ }^{29}$.

For argon-39 our values for iron meteorites are in agreement with other results. Larger discrepancies occur for Sikhote-Alin. It is expected that this large meteorite may have an argon-39 concentration of at the most half of that of a small meteorite exposed in a $4-\pi$ geometry. Thus we have to account for a maximum argon-39 value of about $40 \mathrm{dpm} / \mathrm{kg}$ for a small iron meteorite.

The argon-39 values for stone meteorites are higher than the average values reported by other laboratories. We think, however, that a contamination with argon-39 is very improbable. The high argon-39 values are therefore in the same line as the high tritium values.

29 In the past, tritium contamination of a collection of meteorites was discovered in the Max-Planck-Institut for Chemistry in Mainz where tritium was used for other studies. We cannot exclude with certainty a similar occurence in our case, but no indication of such a contamination was discovered. We are grateful to Professor H. WäNKE for drawing our attention to this possibility and also for useful criticism. 
We have carefully studied the possibility of large systematic calibration errors in our procedure; however, to bring all our measurements a factor of 2 or more down, counting efficiencies between $130 \%$ and $170 \%$ would result. As we have used a series of about 10 argon-39 counters and about 20 tritium counters, different electronic channels and different anti-coincidence arrangements, we feel safe in excluding large systematic counting errors.

\subsection{Production rates}

Tritium and argon-39 production rates were calculated for four different meteorites using crosssections ${ }^{30}$ and cosmic-ray flux densities ${ }^{31,32 a, b}$ from the literature. For elements for which the tritium production cross-sections were not measured directly we interpolated the production cross-sections for these elements by using a $\sqrt[3]{A^{2}}$ dependence. The ratio $\sigma\left({ }^{38} \mathrm{Ar}\right) /\left({ }^{39} \mathrm{Ar}\right)$ for iron was taken equal to 2 for all energies. Experimental values exist for 600 $\mathrm{MeV}^{30}$ and $2 \mathrm{GeV}^{16}$. The argon-39 production from $\mathrm{K}$ and $\mathrm{Ca}$ was taken as $7450 \mathrm{dpm} / \mathrm{kg} \mathrm{K}$ and $60 \mathrm{dpm}$ $/ \mathrm{kg} \mathrm{Ca}$, respectively ${ }^{8 \mathrm{~d}}$. The cosmic-ray spectrum at a depth of $10 \mathrm{~g} / \mathrm{cm}^{2}$ and $100 \mathrm{~g} / \mathrm{cm}^{2}$ was taken from ARNOLD et al. ${ }^{31}$.

The results of the calculation are given in Table 5; from this we can see that the tritium production should be nearly the same for all meteorites and that the differences between the production at $10 \mathrm{~g}$ $/ \mathrm{cm}^{2}$ and $100 \mathrm{~g} / \mathrm{cm}^{2}$ depth are small. The argon-39 production rate for the different meteorites varies considerably. It is interesting to note that the estimated values are on the average a factor of $2-3$ lower than our measured values for tritium and argon-39 in the case of stone meteorites.

Assuming a secondary-particle spectrum like the one given by ARNOLD et al. ${ }^{31,33}$, which they have derived from the primary cosmic-ray spectrum obtained by McDonald ${ }^{32 a}$, b , we would need an integrated flux above $100 \mathrm{MeV}$ of 15 particles $/ \mathrm{cm}^{2} / \mathrm{sec}$ in order to explain a tritium production of 1.2 tritons $/ \mathrm{min} / \mathrm{g}$, in a meteorite of about $20 \mathrm{~kg}$ postatmo-

30 K. Goebel, H. Schultes, and J. ZÄhringer, CERN 64-12 [1964].

31 J. Arnold, M. Honda, and D. Lal, J. Geophys. Res. 66, 3519 [1961].

${ }^{32}$ a F. McDonald, Phys. Rev. 116, 462 [1959].

32b F. MCDonald and W.WebBer, Phys. Rev. 115, 194 [1959]. spheric mass. This flux is about three times higher than the flux calculated from the assumed spectrum and the absolute intensities given by ARNOLD et al. Several authors have also proposed that the particle fluxes producing tritium and other isotopes must be higher. In particular, the intensity of the galactic radiation in the aphelian region of the meteorite must be higher than the one measured near the earth ${ }^{22,34-36}$.

The measured argon-39 production rate in iron meteorites agrees with the calculated values, but tritium and argon-39 in stone meteorites are $2-3$ times higher than estimated. To explain this we have the following possibilities:

(i) The iron meteorites are larger than the stones' so that the iron samples were shielded and not exposed to the maximum flux densities. The stone meteorites, on the other hand, would have been exposed to a three times higher flux as shielding of the samples in these small objects is negligible.

(ii) Stone and iron meteorites have different space history. The average cosmic-ray intensity is different along the orbits of the meteorites.

The tritium production in stones and the argon-39 production in iron would agree if, in general, the iron samples had been shielded by about $100 \mathrm{~g} / \mathrm{cm}^{2}$ more material than the samples of the stone meteorites. We therefore conclude that for the average stone sample the cosmic-ray flux was less shielded than in the case of the average iron samples and that the cosmic-ray flux above $100 \mathrm{MeV}$ was about a factor of three higher than normally assumed.

Figure 2 indicates that there exists a size dependence of tritium concentration in stone meteorites. As abscissa in Fig. 2 we have tentatively chosen the recovered mass of the meteorites. The size effect, which is often masked by other influences, can only be expected to show if the recovered mass is related to the pre-atmospheric dimensions of the meteorite. As could be expected from the high-energy production mechanism, the tritium production per gramme rises with increasing size of the meteorite to a maxi-

33 In the original paper of ARNOLD et al. are some typographical errors concerning the formula of the particle flux densities (Lal personal communication). We used a corrected copy.

34 J. Geiss, H. Oeschger, and P. Signer, Z. Naturforsch. 15 a, 1016 [1960].

35 H. Neher, J. Geophys. Res. 72, 1527 [1967].

36 J. O'Gallagher and J. Simpson, Astrophys. J. 147, 819 [1966]. 


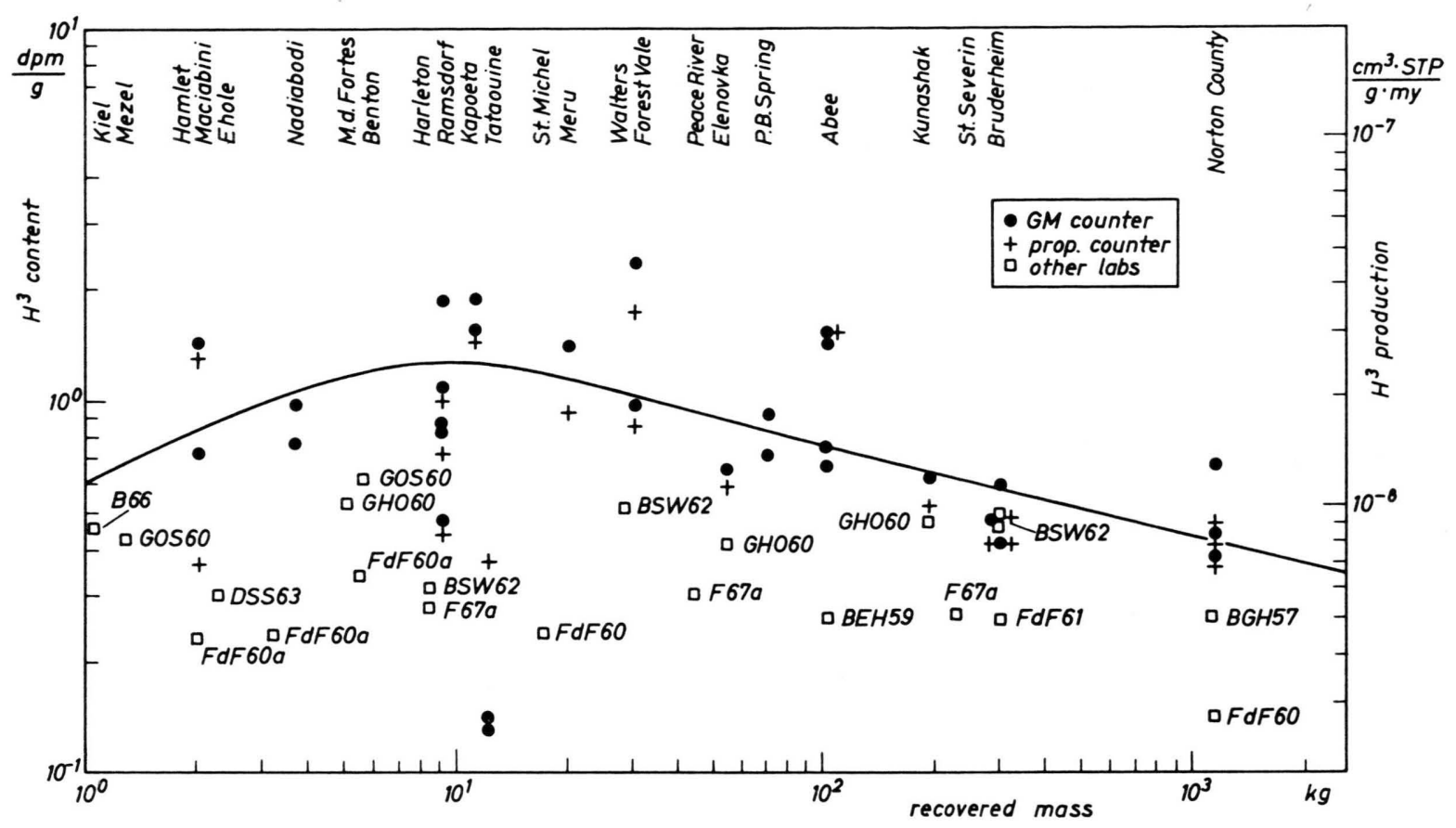

Fig. 2. Tritium content in stone meteorites: B $66^{19}, \mathrm{BEH} 59^{9}$, BGH $57^{14}$, BSW $62^{10}$, DSS $63^{16}, \mathrm{~F} 67 \mathrm{a}^{22}, \mathrm{FdF} 60^{13}, \mathrm{FdF} 61^{11}$, $\mathrm{FdF} 60 \mathrm{a}^{21}$, GHO $60^{12}$, GO $60^{20}$.

mum and then decreases slowly due to absorption of the producing radiation. ANDERS ${ }^{37}$ reviewed the different estimates for the $r / R$ ratio ( $r=$ post-atmospheric radius, $R=$ pre-atmospheric radius). When $r / R=0.7$ - or $m / M=1 / 3$ - taken constant for all meteorites (a certainly crude assumption) we find from our curve in Fig. 2 a maximum of the tritium production for a meteorite with an original mass of about $40 \mathrm{~kg}$. This also agrees with direct measurements of BEGEMANN and VILCSEK ${ }^{38}$ for Norton County and Abee; $m / M$ is found to be 0.45 and 0.60 , respectively. Taking the density as $3.4 \mathrm{~g} / \mathrm{cm}^{3}$, this corresponds to about $20 \mathrm{~cm}$ radius for a spherical object. The recovered samples of such a meteorite must come from a depth-region where the tritium production can be expected to be constant. CRESSY ${ }^{39}$ found a size dependence of the ${ }^{59} \mathrm{Ni}$ in stone meteorites with a peak at $90 \mathrm{~kg}$. The highly size dependent neutron flux densities estimated from ${ }^{36} \mathrm{Cl}$ production for Norton County and Abee ${ }^{38}$ al-

37 E. Anders, The Moon, Meteorites and Comets, University of Chicago Press 1963, Vol. IV, p. 402.

38 F. Begemann and E. Vilcsek, Z. Naturforsch. 20 a, 533 [1965].

39 P. Cressy, Report Nucl. Chem. Res. at Carnegie Inst. of Technology, June 1963, p. 78. low to calculate the tritium production due to neutron capture in $\mathrm{Li}$. In the case of Abee which is the Li-richest meteorite in our list, the tritium production due to neutrons is much below $0.01 \mathrm{dpm} / \mathrm{g}$.

The size dependence of the tritium production by high-energy spallation can explain the general trend of the average tritium values given in Table 3 , but cannot explain the large individual fluctuations of the values.

Besides the discussed tritium production by highenergy particles and slow neutrons, we have also to consider other sources for tritium. There exists, first, the possibility that isotopes like ${ }^{3} \mathrm{He}$ and tritium are gathered from the solar wind along those parts of the meteoritic orbit which are near the sun $11,16,22$. In most of the cases the surface layer in which tritium has been accumulated will be lost in the passage through the atmosphere. It is generally assumed that at least $10 \mathrm{~g} / \mathrm{cm}^{2}$ are ablated ${ }^{40}$. However, KAYE ${ }^{41}$ finds from ${ }^{59} \mathrm{Ni} /{ }^{53} \mathrm{Mn}$ ratio that some surface areas

40 E. Fireman, J. De Felice, and D. Tilles, Radioactive Dating, IAEA, Vienna 1963, p. 323.

${ }^{41}$ J. KAYE, Report Nuclear Chemistry Res. at Carnegie Inst. of Technology, June 1963, p. 62. 
of the meteorites did not undergo appreciable ablation. Price et al. ${ }^{42}$ and Cantilaube et al. ${ }^{43}$ arrived at similar conclusions, in studying tracks of heavy cosmic ions in meteorites. FIREMAN et al. ${ }^{44}$ have shown that tritons emitted with kinetic energies $>85 \mathrm{MeV}$ could explain the high tritium decay rates in recovered materials from satellites. These tritons penetrate $3-4 \mathrm{~g} / \mathrm{cm}^{2}$ of material. From these measurements the triton flux density between $85 \mathrm{MeV}$ and $200 \mathrm{MeV}$ is estimated to be $20{ }^{3} \mathrm{H} / \mathrm{cm}^{2} /$ sec.

Further, solar protons of several tens of $\mathrm{MeV}$ energy and of a flux density more than one order of magnitude higher than the galactic cosmic-ray flux densities could also provoke considerable tritium production. LAL et al. ${ }^{45}$ have recently calculated the nuclear effects of solar particles in the nearsurface region of meteorites. Tritium production between $10 \%$ and $50 \%$ of the galactic production can be expected. However, Lal used for the tritium production a cross-section of $4 \mathrm{mb}$ in the energy interval between 20 and $250 \mathrm{MeV}$. According to Ref. ${ }^{30}$ we would rather propose a cross-section of $8 \mathrm{mb}$, which means that in the most favourable cases the tritium production near the surface due to solar protons could be nearly twice the production due to galactic protons. Therefore, in the pre-atmospheric body, tritium fluctuations of a factor of $2-3$ could be expected. The different values given in Table 3, however, remain unexplained as not all the samples with high values were located near the original surface. In this situation we used for the following calculations of the exposure ages average tritium values for each individual meteorite. From the results obtained for the different meteorites, we do not have sufficient evidence to assume that the tritium production rate for all meteorites is the same.

\subsection{Tritium in the rim of iron meteorites}

Some samples from the surface of the iron meteorites Sikhote-Alin and Aroos, have been examined for tritium. In these surface samples the tritium per gramme of meteorite varies considerably, but if the tritium decay rate measured is related to the individual surface area of the samples the tritium content is remarkably constant, as already shown in Table 4. For the same meteorites, the tritium contents of inner samples are shown for comparison. For the inner samples, the tritium concentrations are well below the calculated values of about 0.3 $\mathrm{dpm} / \mathrm{g}$ of iron (see Table 5). According to the curve of Fig. 2 and from the calculated ratio of 0.75 for tritium content in iron and stone meteorites at $100 \mathrm{~g} / \mathrm{cm}^{2}$ depth, we would expect for Aroos a tritium content of $0.5 \mathrm{dpm} / \mathrm{g}$.

We have carefully checked the possibility of "tritium contamination" during the terrestrial residence of the samples, in particular in our laboratory, but so far could not find any hint of such a possibility. Hence we have to conclude that the tritium in the surface of these two iron meteorites is of extraterrestrial origin.

With an expected tritium concentration of 0.5 $\mathrm{dpm} / \mathrm{g}$ in iron-nickel material, the average value of $2.7 \mathrm{dpm} / \mathrm{cm}^{2}$ found in the rim of the meteorites corresponds to a tritium-containing layer of $5-6 \mathrm{~g}$ $/ \mathrm{cm}^{2}$ or $6-8 \mathrm{~mm}$ thickness. So, if only a layer of $6-8 \mathrm{~mm}$ in the rim would retain the tritium expected to be produced in outer space, the measured decay rate could be explained. It would then follow that all the rest of the iron meteorite has lost its tritium.

Tritium losses in space are judged, according to the ${ }^{3} \mathrm{He}$ content of the iron, as being in general

\begin{tabular}{|c|c|c|c|c|c|}
\hline Meteorites & $\begin{array}{c}{ }^{3} \mathrm{H}(\mathrm{d} / \mathrm{d} \\
\text { At } 10 \mathrm{~g} / \mathrm{cm}^{2} \\
\text { depth }\end{array}$ & $\begin{array}{l}\mathrm{pm} / \mathrm{g}) \\
\text { At } 100 \mathrm{~g} / \mathrm{cm}^{2} \\
\quad \text { depth }\end{array}$ & Meteorites & $\begin{array}{l}{ }^{39} \mathrm{Ar}(\mathrm{d} \\
\text { At } 10 \mathrm{~g} / \mathrm{cm}^{2} \\
\text { depth }\end{array}$ & $\begin{array}{l}\mathrm{pm} / \mathrm{kg}) \\
\text { At } 100 \mathrm{~g} / \mathrm{cm}^{2} \\
\text { depth }\end{array}$ \\
\hline Iron & 0.367 & 0.305 & Iron & 37 & 29 \\
\hline Abee & 0.428 & 0.370 & Forest Vale & \multirow{2}{*}{\multicolumn{2}{|c|}{$\begin{array}{r}14.4 \\
7.5\end{array}$}} \\
\hline Macibini & 0.436 & 0.387 & Kapoeta & & \\
\hline Norton County & 0.453 & 0.398 & Norton County & \multicolumn{2}{|c|}{2.3} \\
\hline
\end{tabular}

Table 5. ${ }^{3} \mathrm{H}$ and ${ }^{39} \mathrm{Ar}$ production rates.

42 P. Price, R. Rajan, and A. Tamhane, J. Geophys. Res. 72, 1377 [1967].

43 Y. Cantelaube, M. Maurette, and P. Pellas, Dating and Methods of Low Level Counting, IAEA, Vienna 1967, p. 215 .
44 E. Fireman, J. De Felice, and D. Tilles, Phys. Rev. 123, 1935 [1961].

45 D. Lal, R. Rajan, and V. Venkatavaradan, Geochim. Cosmochim. Acta 31, 1859 [1967]. 
small. Tritium losses from iron meteorites during their terrestrial residence might be high according to Hintenberger et al. ${ }^{46}$, due to weathering of the grain metal surface. Tritium loss after the fall is also proposed by FisHeR ${ }^{47}$ as a reasonable explanation for the "missing tritium". To check whether tritium was retained by the iron during the melting of the meteorite sample in the laboratory, BAINBRIDGE et al. ${ }^{10}$ burnt some samples from Aroos. They did not find any tritium.

A very important experiment was carried out by FeCHTIG et al. ${ }^{48}$ who produced tritium in the Sikhote-Alin meteorite by bombardment with $600 \mathrm{MeV}$ protons. The diffusion behaviour of this tritium should be exactly the same as the diffusion of cosmogenic tritium in the meteorite during its terrestrial residence. The authors conclude that the tritium can escape from the iron meteorites within a few weeks or months after their fall. In space the meteorites retain tritium until it decays into ${ }^{3} \mathrm{He}$, but when the meteorite hits the earth it shatters, or cracks, or is weathered along grain boundaries and tritium is permitted to diffuse out of the meteorite. Fisher supposes that in this way Sikhote-Alin has lost its tritium on earth.

LOVERING et al. ${ }^{49}$ have shown that a post-atmospheric layer of $5-7 \mathrm{~mm}$ was subjected to temperature changes during the passage through the atmosphere. In this surface rim a temperature gradient from low temperatures up to $1500{ }^{\circ} \mathrm{C}$ existed for a short time interval. Therefore different types of alterations in the rim due to certain temperature conditions can be expected ("Temperature alteration rim").

Taking into consideration the above arguments, we would like to propose some hypotheses to explain our results on tritium concentration in the rim:

i) The heat-mechanical shock when entering the atmosphere can influence the crystal structure so that the number of crystal dislocations is increased considerably in the rim. These dislocations are capable of trapping hydrogen. This bond should be strong enough to prevent diffusion of the rim-hydrogen.

46 H. Hintenberger, L. Schultz, and H. Wänke, Z. Natur forsch. 21 a, 1147 [1966].

47 D. Fisher, J. Geophys. Res. 72, 1351 [1967].

48 H. Fechtig, J. Festag, and H. Schultes, Z. Naturforsch. 22 a, 765 [1967]. ii) The large range of temperatures near the meteorite surface and the presence of impurities makes the formation of several stable hydrides possible. In this bound form hydrogen can be retained in the meteorite.

iii) Certain compounds of iron, which could be formed in the rim during the passage through the atmosphere due to the high temperature, are capable to absorb large amounts of hydrogen.

\section{Exposure Ages}

For the estimation of exposure ages we have used the pairs ${ }^{3} \mathrm{H}-{ }^{3} \mathrm{He}$ and ${ }^{39} \mathrm{Ar}-{ }^{38} \mathrm{Ar}$. We assume:

i) the production of ${ }^{3} \mathrm{H}$ and ${ }^{3} \mathrm{He}$ in meteorites by cosmic radiation is about the same: we used the ${ }^{3} \mathrm{H} /{ }^{3} \mathrm{He}$ production ratio 1.2 ;

ii) for ${ }^{38} \mathrm{Ar}$ and ${ }^{39} \mathrm{Ar}$ a production ratio for the whole energy spectrum equal to that measured at $600 \mathrm{MeV}$; we used ${ }^{38} \mathrm{Ar} /{ }^{39} \mathrm{Ar}=2$;

iii) the spallation products are accumulated without large distortion during the whole time interval in question; factors such as diffusion and space erosion which influence the estimation of exposure ages are considered as being small.

The spallogenic ${ }^{38} \mathrm{Ar}$ and ${ }^{3} \mathrm{He}$ were measured by KIRSTEN et al. ${ }^{50}$. The contribution of primordial gases to ${ }^{3} \mathrm{He}$ and ${ }^{38} \mathrm{Ar}$ was deduced; the final values used are given in Tables 6 and 7 which present the exposure ages of stone and iron meteorites, including results of other laboratories. In column 4 of Table 6 we have listed the ages derived with an average size-dependent tritium production rate (curve Fig. 2). As can be seen, the ages in this column deviate sometimes considerably from the values in column 3 . FISHER ${ }^{47}$ and HEYMANN ${ }^{57}$ already pointed out that individual production rates lead to quite important variations in the published exposure ages. Our exposure ages do not show clustering as proposed by Geiss, Oeschger, and Signer ${ }^{34}$. It is generally assumed that diffusion of rare gases and tritium does not play an important role in the minerals forming the stone meteorites as the space temperature of meteorites is low 58,59 and the diffusion constants are small ${ }^{46,58,60-62}$. Diffusion losses of argon in irons are in general very low.

\footnotetext{
" J. Lovering, L. Parry, and J. Jaeger, Geochim. Cosmochim. Acta 19, 156 [1960].

50 T. Kirsten, D. KrankowSKy, and J.Zähringer, Geochim. Cosmochim. Acta 27, 13 [1963].
} 


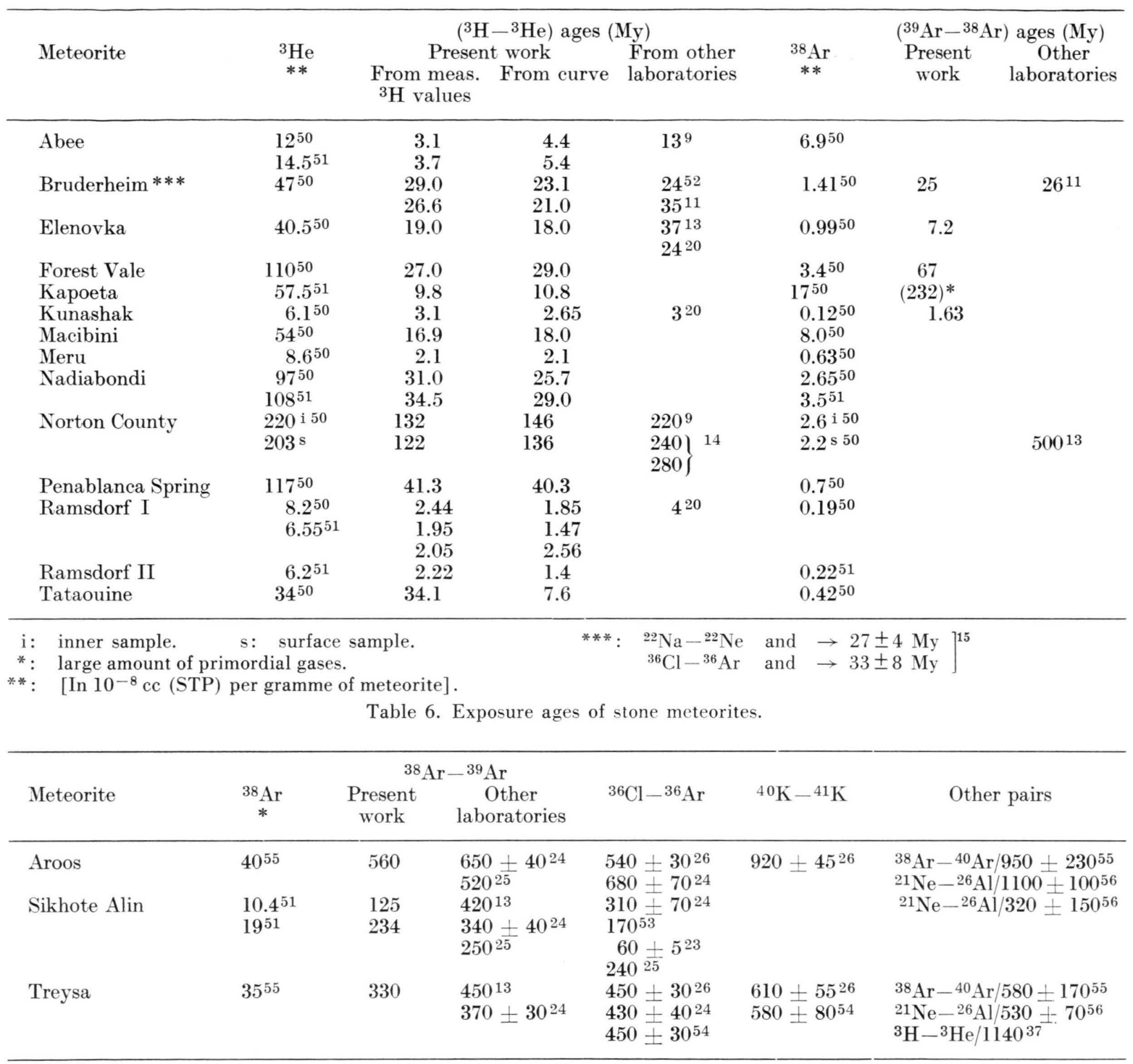

* In $10^{-8}$ cc (STP) per gramme of meteorite.

Table 7. Exposure ages of iron meteorites (Ages in millions of years).

Acknowledgements

We would like to thank Prof. W. Gentner for his support and interest in this work and Dr. J. Z̈̈HRINGER for his collaboration concerning the rare gas measurements. For the supply of meteorite samples we are deeply

51 J. Zähringer, Personal communication.

52 P. Signer, J. Geophys. Res. 66, 2560 [1961].

53 D. FisCHER and O. SCHAEFFER, BNL 4537 [1960].

54 H. Voshage and H. Hintenberger, Radioactive Dating, IAEA, Vienna 1963, p. 367.

55 P. LÄmmerzahl and J. Zähringer, Max-Planck-Institut, Heidelberg, Report 1966/V/1.

56 M. Lipschütz, P. Signer, and E. Anders, J. Geophys. Res. 70, 1473 [1965].

57 D. Heymann, Report EFINS 66-62 [1962]. indebted to all the persons mentioned in Table 3 and 4. We express our gratitude to Messrs. G. Droz and $\mathrm{CH}$. Nichols for their technical assistance. The assistance of Mr. H. Schultes in the elaboration of the experimental procedure is very much appreciated.

58 H. Fechtig and W. Gentner, Z. Naturforsch. 20 a, 1686 [1965].

59 F. Houtermanns, E. Jäger, M. Schön, and H. Stauffer, Ann. Phys. 20, 283 [1957].

${ }^{60}$ H. Hintenberger, H. König, and H. Wänke, Z. Naturforsch. 17, 1092 [1962].

61 H. Hintenber Ger, E.Vilcsek, and H.Ẅ̈nke, Max-PlanckInstitut für Chemie, Mainz, Report No. 56 [1964].

62 H. Fechtig, W. Gentner, and P. Lämmerzahl, Geochim. Cosmochim. Acta 27, 1149 [1963]. 